\title{
School Alienation: A Construct Validation Study
}

\author{
Julia Morinaja $^{\mathrm{a}}$, Jan Scharf ${ }^{\mathrm{b}}$, Alyssa Grecu ${ }^{\mathrm{b}}$ \\ Andreas Hadjar ${ }^{b}$, Tina Haschera, Kaja Marcin ${ }^{a}$ \\ ${ }^{a}$ University of Bern, Switzerland \\ ${ }^{b}$ University of Luxembourg, Luxembourg \\ article received 27 March / revised 8 June / accepted 16 July / available online 25 July
}

\begin{abstract}
Early identification of school alienation is of great importance for students' educational outcomes and successful participation in society. This study examined the psychometric characteristics of a newly developed assessment instrument, the School Alienation Scale $(S A L S)$, to measure school alienation among primary and secondary school students. The SALS consists of three school-related domains, namely, classmates, teachers, and learning. Based on the responses of Swiss (1) and Luxembourgish (2) students from two schoolspecific cohorts - primary (grade $4 ; n_{1}=486, n_{2}=503$ ) and secondary schools (grade 7; $\left.n_{1}=550, n_{2}=534\right)$, we assessed instrument reliability, validity, and cross-cultural equivalence. The scale showed evidence of reliability and internal validity across two samples, confirming that the hypothesized first-order three-factor model fits the data better than several alternative models. The results of measurement invariance tests revealed that the measurement model operated equally well for primary and secondary school students in both countries. The construct validity of the SALS was additionally supported by demonstrated criterion-related validity. Specifically, school alienation domains were negatively associated with positive attitudes to and enjoyment in school; social problems in school were positively related to alienation from classmates and teachers. Our key contributions to the measurement of school alienation are the disclosure of the core domains of school alienation, development of a reliable and valid instrument, and justification for its use. Therefore, the results of this study have important implications for further theoretical work in alienation research and contribute to comparative research by examining the construct of school alienation in different educational settings.
\end{abstract}

Keywords: School alienation; Construct validity; Criterion validity; Measurement invariance

Corresponding author: Julia Morinaj, Institute of Educational Science, University of Bern, Fabrikstrasse 8, 3012 Bern, Switzerland, iuliia.morinaj@edu.unibe.ch DOI: http://dx.doi.org/10.14786/flr.v5i2.298 


\section{Introduction}

Education crucially supports successful participation in society and develops the existing body of knowledge. A knowledge base and skills acquired through schooling provide individuals opportunities to act effectively in a rapidly changing world. Additionally, only a well-educated population can contribute significantly to the community and the economy (Becker, 1994; Seetanah, 2009; Vila, 2000; Zhang \& Zhuang, 2011). For these reasons, societies have a genuine interest in providing young people various educational opportunities. However, children's learning begins when they are born (Krumboltz, 2009) when they start observing their environment, and it continues throughout their lifetime. Indeed, the majority of young children come to school filled with curiosity, creativity, and a strong desire to learn (Lumsden, 1994).

However, there is substantial evidence that students' intrinsic academic motivation and interest in learning at school significantly decline over time (Eccles \& Midgley, 1990; Gottfried, Fleming, \& Gottfried, 2001; OECD, 2004). Not only do these processes co-occur with considerable social, physical, cognitive, emotional, and behavioral changes during adolescence (Eccles, Brown, \& Templeton, 2008; Schunk \& Meece, 2005), but they are also associated with significant changes in family relations, peer affiliation, school and home environments (Schunk \& Meece, 2005). Such shifts can be accompanied by school alienation, delinquency, and dropping out of high school (Eccles \& Gootman, 2002), pointing to a mismatch between adolescents' needs and their environments (Archambault, Janosz, Morizot, \& Pagani, 2009b; Eccles \& Midgley, 1989). In other words, adolescents whose environments do not fulfill their needs are more likely to become psychologically and physically disengaged, and eventually alienated from school (Eccles \& Roeser, 2009; Gutman \& Eccles, 2007).

The rising interest in school alienation has led to a better understanding of the phenomenon per se (Hadjar \& Lupatsch, 2010; Hascher \& Hadjar, 2017; Hascher \& Hagenauer, 2010). Much less attention, however, has been paid to the development and validation of instruments that measure school alienation. To ensure meaningful inferences from a theoretical construct and to justify instrument use for further research and praxis, it is of utmost importance to carefully design and validate the construct of school alienation (Arnold, Arad, Rhoades, \& Drasgow, 2000; Clark \& Watson, 1995). Moreover, measurement validation is inevitably bound to theory development and theory testing (Zumbo, 2009). Thus, construct validity, based on theoretical and statistical evidence, lies at the heart of the present study.

In this study, we introduce a new multidimensional perspective on school alienation. In particular, we developed the School Alienation Scale (SALS) as an assessment instrument used in the binational research project, School Alienation in Switzerland and Luxembourg (SASAL), to identify students' negative attitudes toward classmates, teachers, and learning during primary and secondary education. Such measurement enables gathering important data about the issues students face in daily school life. Unlike previous studies on school alienation (e.g., Martin, 2008; Newmann, 1992; Rovai \& Wighting, 2005), which consider a single academic setting (e.g., American secondary schools, virtual classrooms), we examined the development of school alienation in different educational settings - Switzerland and Luxembourg. The selection of these countries, which have some differences and share some similarities, is meaningful from the perspective of comparative educational research. In addition, comparative research enables testing the instrument in various settings and provides additional evidence of construct validity. The main objectives of this research are to gain a thorough understanding of the phenomenon of school alienation and to develop and validate a new theoretically-based measure of school alienation.

Here, we first describe the major concepts of school alienation, followed by the guiding theoretical issues regarding instrument construction. Second, we provide data on instrument reliability, validity, and crosscultural equivalence, based on research conducted in Luxembourg and the Swiss canton of Bern. Parallel analyses were conducted across primary and secondary school students and across countries to demonstrate the replicability of findings. Finally, we discuss the study's results and implications for future research. 


\subsection{Conceptualization of school alienation}

The term alienation comes from the Latin alienatus, meaning "estranged," which in turn originated from alius, meaning "other" or "another" (Watt, 2000). The concept of alienation has been introduced from sociological, psychological, philosophical, theological, and historical perspectives and applied to various contexts. For example, Marx primarily focused on the concept of alienation in the economic system. Moreover, subsequent alienation research has shown that the problem of alienation also arises in highly centralized and formalized organizations (Blauner, 1964; Aiken \& Hage, 1966), family life (Kelly \& Johnston, 2001), work settings (Hirschfeld \& Feild, 2000; Shantz, Alfes, \& Truss, 2014) as well as religious (Exline, Yali, Sanderson, 2000), political (Finifter, 1970; Seeman, 1975; Pantoja \& Segura, 2003), and medical contexts (Young, 1984). Although alienation appears to be a strictly contextual construct (Safipour, Schopflocher, Higginbottom, \& Emami, 2011), at a general level it may be characterized as a kind of estrangement, distancing, or separateness from a former or a normal state, leading to some sort of loss (Railton, 2013).

So far, relatively little is known about alienation in educational settings. However, recent studies essentially contributed to the development of school alienation research, specifying the characteristics of educational and social learning environments necessary for the prevention of school alienation (Dickey, 2004; Hadjar, Backes, \& Gysin, 2015; Hadjar \& Lupatsch, 2010; Hascher \& Hadjar, 2017; Hascher \& Hagenauer, 2010; Osin, 2009). Oftentimes, youngsters who like school at the beginning may later become estranged from learning and develop negative attitudes toward school, hurtling into school alienation, and over time, even into dropping out (Archambault et al., 2009b; Eccles \& Alfeld, 2007). Different students, whether they study in elite private or inner-city schools, undoubtedly experience the same problem (Sidorkin, 2004). Moreover, it is especially in adolescence that youth often deal with numerous stressful situations at school (Safipour et al., 2011). For example, students who see little practical value in learning and its relevance outside of school, who experience poor relationships with teachers, or who suffer because of classmates may feel like outsiders. In the framework of the SASAL project, we conceptualize this feeling of estrangement from the social (i.e., classmates and teachers) and academic aspects of schooling (i.e., learning), including cognitive and emotional components, as school alienation (Hascher \& Hadjar, 2017). In a school mostly free of alienation, we would expect students to maintain courteous relationships with classmates and school staff members and to engage actively and meaningfully in classroom and school activities.

Suffice it to say that educational alienation cannot be dismissed as a temporary aberration, as it is rather a part of education (Sidorkin, 2004). There is a strong likelihood that adolescents who are alienated from school will not accomplish their basic educational goals (Archambault, Janosz, Fallu, \& Pagani, 2009a). As a result, alienated students leave school with numerous negative experiences, including deviant behaviors, difficulties in fitting in, low participation in school activities, depression, running away, early sexual activity, conflicts with families, school withdrawal, limited education, failed attachment to school, or a lack of interest in further academic qualification (Brown, Higgins, \& Paulsen, 2003a; Farrow, 1991; Frey, Ruchkin, Martin, \& Schwab-Stone, 2009; Hascher \& Hagenauer, 2010; Tarquin \& Cook-Cottone 2008). School alienation can therefore lead to a process of exclusion from a society that is increasingly based on learning. Hence, the early diagnosis and understanding of school alienation are of great importance for the community, including educators, school staff members, and parents (Brown et al., 2003a; Stamm, Kost, Suter, Holzinger, \& Stroezel, 2011).

Currently, most measurements of school alienation draw upon some of the alienation categories addressed by Seeman (1959) and Dean (1961), including powerlessness, meaninglessness, normlessness, isolation, and self-estrangement (e.g., Brown, Higgins, Pierce, Hong, \& Thoma, 2003b; Mau, 1992). For example, recent studies explicitly focused on the four alienation dimensions most closely associated with the school context, namely, powerlessness, meaninglessness, normlessness, and social estrangement (Brown et al., 2003b; Çağlar, 2013; Kocayörük \& Simsek, 2015; Mau, 1992). Similarly, another study developed an alienation-based framework for student experience in higher education, concentrating on the three categories, such as powerlessness, meaninglessness, and self-estrangement (Barnhardt \& Ginns, 2014). Despite the relative popularity of recognizing the above-mentioned categories as an alienation construct, only a very 
limited number of studies have measured it (Brown et al., 2003b). Some researchers have addressed the phenomenon of school alienation by investigating its correlates. Correlations are demonstrated repeatedly, for example, between school alienation and student participation (Altenbaugh, Engel, \& Martin, 1995; Carlson, 1995; Newmann, 1992), between school alienation and academic achievement (Johnson, 2005; Reinke \& Herman, 2002), between school alienation and teacher and peer support (Altenbaugh et al., 1995; Ghaith, Shaaban, \& Harkous, 2007; Hascher \& Hagenauer, 2010), and between school alienation and school withdrawal (Liu, 2010). Murdock (1999) has focused on the behavioral aspect of school alienation, based on engagement in school tasks and self-reported disciplinary problems. Further, the phenomenon of school alienation was also studied in the context of motivation research, especially in regard to student (dis)engagement. Some researchers used the term disengagement as a synonym for school alienation (Altenbaugh et al., 1995), although later they described a vicious cycle in which alienation encourages further disengagement leading to more alienation. Alienation was also described as a subdimension of academic amotivation (Legault, Green-Demers, \& Pelletier, 2006). Another empirical study viewed engagement as a positive counterpart to alienation (Case, 2008). However, the shortcomings of those approaches lie in the finding that the two constructs are not symmetrically opposite (Schabracq \& Cooper, 2003).

A variety of viewpoints in alienation research indicates a lack of consistency among the operationalizations of school alienation. In accordance, it may not be surprising that there is little consistency in its measurement (Barnhardt \& Ginns, 2014; Brown et al., 2003b; Çağlar, 2012; Carlson, 1995; Hyman, Cohen, \& Mahon, 2003; Johnson, 2005; Mau, 1992; Murdock, 1999). Although most instruments recognized the multidimensional nature of school alienation, it is still obscure whether school alienation is a general or rather a domain-specific construct and what are its key elements. Moreover, there is a lack of information regarding the validity and reliability of existing instruments that measure school alienation.

The identification of factors underlying student feelings of school alienation and alleviation of unfavorable consequences is important for understanding the true impact alienation may have on school success. In the alienation literature, several reasons of school alienation are discussed. Oftentimes, student alienation is conceptualized as the result of three experiences. First, school subjects appear irrelevant to some students and they rarely see the connection between learning at school and their social realities (Çağlar, 2013). As a result, they estrange themselves from the learning process and develop negative attitudes toward the school (Altenbaugh et al., 1995). Second, teachers behave differently toward students in the same classroom (Babad, 1992; Hughes, Gleason, \& Zhang, 2005; Jussim \& Eccles, 1992; Jussim, Eccles, \& Madon, 1996; McKown \& Weinstein, 2008). For example, teachers tend to provide more emotional support, more favorable feedback, and more challenging learning opportunities to high achievers. At the same time, they expect troublesome behavior from difficult students and impose more restrictive actions upon those students (Baker, 1998). Accordingly, as a reaction, students may respond to these disciplinary actions with more disobedience which in turn may lead to further alienation and distancing from teachers (Kagan, 1990). Third, students feel not accepted by their classmates, experiencing non-fulfilment of their psychological and social needs (Baker, 1998). Peer rejection can result in student academic and socioemotional misfortune in a school environment as well as a lack of identification with the school system (Buhs \& Ladd, 2001; Ladd, 1999; Ladd, Birch, \& Buhs, 1999). In other words, alienated students may withdraw from peers, teachers, learning, and eventually school itself (Altenbaugh et al., 1995). Research on student withdrawal has also distinguished between the academic (e.g., learning, academic performance) and social (e.g., interaction with classmates and teachers) domains of the educational institution, suggesting that despite close interrelation between the two domains, a student may be integrated into one domain without being sufficiently integrated into the other (Tinto, 1975, 1993). These theoretical propositions suggest that in a school setting students can be alienated in academic and/or social domains.

Considering the multidimensional nature of the school alienation phenomenon and that attitudes are usually directed toward specific situations, objects, or behavior (Honkanen, Verplanken, \& Olsen, 2006), this study suggests a more holistic approach. Specifically, we propose that school alienation consists of three school-related domains - classmates, teachers, and learning - considering them as interrelated but relatively independent dimensions. In other words, we address school alienation as a construct of a domain-specific 
nature. Accordingly, we developed the School Alienation Scale (SALS) as a carefully constructed, comprehensive, psychometrically sound, and brief standardized assessment instrument that can be used to diagnose students' negative attitudes toward classmates, teachers, and learning during primary and secondary education. More precisely, it measures whether students are alienated from classmates, and/or teachers, and/or learning at school. Students may become alienated in one, two, or all three domains. In the latter case, students experience negative attitudes toward both social actors and academic aspects of schooling.

\subsection{Rationales for questionnaire construction}

Prior to constructing the SALS to assess student alienation from school, we articulated several basic principles. First, we conceptualized the target construct to assure the coherence of the initial item pool. To be specific, the three school alienation dimensions of classmates, teachers, and learning comprised both emotional (i.e., a student' feelings toward school) and cognitive (i.e., a student's beliefs, perceptions, knowledge, assumptions, and judgments of school) aspects. Second, we specified the association between these aspects, taking into account that historically, cognitive and emotional processes were studied separately (Hilgard, 1980; Snow, Corno, \& Jackson, 1996).

For years, psychologists have been trying to solve the "chicken and egg" causality dilemma. However, recent research is based on the idea that cognition cannot be separated from individual's emotions and feelings; it tends to examine them as interwoven psychological processes, one leading to another, in an ongoing cycle (Dai \& Sternberg, 2004; Dweck, Mangels, \& Good, 2004; Eisenberg, 2014; Linnenbrink \& Pintrich, 2004; Pessoa, 2008). There is scientific evidence that positive emotions stimulate rigorous thinking, facilitating application of existing knowledge (Isen, 2004). Moreover, emotions are essential not only in the relationship between individuals and their environment, but also in group processes, such as group members (for example, a school class) sharing similar emotional experiences (Aritzeta et al., 2016). When members of a class feel they are a part of the class, they are most likely to pursue common goals (e.g., learning, getting good marks, or graduating). Kreitler (2013) likewise perceived emotions as motivational forces that influence activation and functioning of cognition. In other words, emotion and cognition are different sides of the same coin, working jointly in the process of intellectual functioning (Dweck et al., 2004; Wimmer, 2013; Zihl, Szesny, \& Nickel, 2013), and do not act independently of each other (Kreitler, 2013). Therefore, in this study we scrutinized the complex interplay between emotion and cognition in alliance, and emphasized the difficulty of setting boundaries between them.

Furthermore, we also decided whether school alienation should be measured with general or subjectspecific items. Recent studies addressed school alienation not as subject-specific, but rather as a general negative orientation toward social actors and/or learning in school (Hadjar \& Lupatsch, 2010; Hascher \& Hagenauer, 2010; Hadjar, Backes, \& Gysin, 2015). Consequently, in this study we decided to measure school alienation at a more general level. Nevertheless, we acknowledge that students' feelings and beliefs may vary depending on school subject (Goetz, Frenzel, Pekrun, \& Hall, 2006).

\subsection{Aim and hypotheses}

The current study was designed to illustrate psychometric characteristics of a newly developed selfreport instrument to assess school alienation among primary and secondary students, based on certain theoretical and conceptual considerations. Validity theorists emphasize the importance of constructing a cohesive validity argument that integrates several sources of evidence to support the construct validity and use of the instrument (AERA, APA, \& NCME, 2014). The unitary concept of validity still remains a widely used approach (Chan, 2014; Sireci, 2009). Therefore, we sought to provide a consistent approach for examining the construct validity of the SALS. We first assessed the reliability of the scale in terms of internal consistency of the items. We then explored the factorial structure of the SALS and tested several competing models of school alienation by means of confirmatory factor analysis. Next, we estimated measurement invariance across two cohorts, two countries, and gender to ensure that the instrument possessed the same psychometric 
characteristics across various groups. Finally, we assessed criterion-related validity, as an additional evidence of construct validity, to investigate the relationship between the SALS and external criteria.

With respect to a suggested construct validity approach, we tested the following hypotheses. Recognizing the multidimensional nature of school alienation, we assumed the SALS developed for diagnosing student alienation from classmates, teachers, and learning to be reliable (Hypothesis 1). Regarding the factorial structure of the SALS, our proposition that students can be alienated from classmates, teachers, or learning at school implied that the instrument should depict a three-factor structure. Hence, the measurement model tested here hypothesized that responses to the SALS could be explained by three first-order factors classmates, teachers, and learning (see Figure 1, Model 3). It was expected that the specified model could be verified and fit the data better than several alternative models (Hypothesis 2).

Furthermore, with the goal of following individuals over time and comparing groups, an instrument should measure the same construct having identical structure across various groups. Therefore, we assessed measurement invariance across different contexts (i.e., Switzerland and Luxembourg), grades (i.e., grade 4 and grade 7), and gender. By establishing measurement invariance, we provide additional evidence of construct validity (Van de Schoot, Lugtig, \& Hox, 2012). We assumed the questionnaire was equally suitable for both primary and secondary school students (Hypothesis 3) in both Switzerland and Luxembourg (Hypothesis 4) and for both boys and girls (Hypothesis 5). However, it is not sufficient to provide only measurement invariance for evaluating validity of the measure.

Criterion-related validity was examined as important evidence of construct validity (Ariño, 2003; Messick, 1995; Vandenberg \& Lance, 2000). The validity of the measurement is also indicated by the correspondence of the relationships between the new measure and other variables to theoretical expectations. Together with the SALS, we administered other scales, including the Well-Being in School Scale (Hascher, 2007). In particular, we examined associations between the domains of school alienation and demonstrably valid dimensions of well-being (Hascher, 2008; Hascher \& Hagenauer, 2011). In keeping with previous research on the association of alienation and well-being (Crinson \& Yuill, 2008; Dekel \& Tuval-Mashiach, 2012; Hall-Lande, Eisenberg, Christenson, \& Neumark-Sztainer, 2007; Ifeagwazi, Chukwuorji, \& Zacchaeus, 2015; Moreno, \& de Roda, 2003; Osin, 2009; Vahedi \& Nazari, 2011), we expected positive attitudes to school and enjoyment in school to be significantly negatively related to the domains of school alienation (Hypothesis 6). Prior research has shown that when students experience positive emotions during school-related activities and interaction with people involved in those activities their alienation decreases (Ifeagwazi et al., 2015). Wellbeing is, thus, viewed as a resource for coping with negative impacts on learning and individual development (Hascher, 2011, 2012). This implies that social problems in school should be positively related to alienation from classmates and teachers (Hypothesis 7). In accordance with Hascher (2010), social discrimination in school was found to diminish student well-being and escalate social problems in school.

Accordingly, the present study was conducted to accomplish three major goals. First, given little agreement on the conceptualization of school alienation, we sought to identify the key elements of school alienation. Second, considering generally acknowledged multidimensional nature of school alienation, we wanted to verify whether school alienation is a general or a domain-specific construct. In addition, we analyzed the interplay between emotion and cognition. Third, we also sought to empirically validate the new theoretically-based instrument to measure school alienation. A carefully designed and psychometrically sound research instrument, based on theory and statistical analysis, would make a valuable contribution to alienation research from theoretical, practical as well as methodological standpoints. 


\section{Method}

\subsection{Participants and procedures}

Data were collected from two cohorts of primary and secondary school students, attending grade 4 and grade 7 , respectively. The sample in this study $(N=2,073)$ consisted of 486 students from primary school $\left(47.3 \%\right.$ male; $M_{\text {age }}=10.3$ years $\left.[S D=.98]\right)$ and 550 students from secondary school $\left(45.2 \%\right.$ male; $M_{\mathrm{age}}=13.0$ years $[S D=.55])$ from the Swiss canton of Bern; and 503 primary school students $\left(54.9 \%\right.$ male; $M_{\text {age }}=9.7$ years $[S D=.75])$ and 534 secondary school students $\left(57.8 \%\right.$ male; $M_{\text {age }}=12.7$ years $[S D=.65]$ ) from Luxembourg. Fifty percent of the students in the Swiss canton of Bern and about $75 \%$ of students in Luxembourg had a migration background (including first- and second-generation immigrants).

Both countries have stratified education systems, offering track selection at the secondary level (EDK, 2015; MENJE \& University of Luxembourg, 2015). The majority of secondary school students in Switzerland studied in schools with various school tracks and ability groups. Just over half of secondary school students $(55 \%)$ studied in the middle track (Sek), 36\% in the lower track (Real), and 8\% in the upper track (Spezsek). On average, primary school students perceived themselves as having good academic performance $\left(M_{\text {perf }}=4.32\right.$ $[S D=.46]$ on a scale from $1=$ poor to $5=$ very good). Secondary school students defined themselves as having above-average academic performance $\left(M_{\text {perf }}=3.69[S D=.57]\right.$ on a scale from $1=$ poor to $5=$ very good $)$.

For the Luxembourgish sample, the largest percentage of students $(34 \%)$ were from the general secondary track (enseignement secondaire), $25.3 \%$ from the technical secondary track (enseignement secondaire technique), $23.2 \%$ from the lowest technical secondary track (régime préparatoire/modulaire), and $17 \%$ were from the project track PROCI (projet pilote "cycle inferieur" de l'enseignement secondaire technique), a comprehensive track within technical secondary education with heterogeneous ability levels. Primary school students, on average, perceived themselves as having good academic performance $\left(M_{\text {perf }}=4.05\right.$ $[S D=.53])$, whereas secondary school students described themselves as having above-average academic performance $\left(M_{\text {perf }}=3.72[S D=.58]\right)$.

Contacts to schools were established through school principals and teachers, who were provided general information about the project, its goals, and benefits of participating. In the former case, principals decided together with teachers about their participation in the study. In the latter case, we contacted teachers directly. Once agreement was reached, we informed school principals about teachers' consent to engage in a project. Random sampling of schools or classes was not possible, because of a high risk of dropout. A main sampling criterion was heterogeneity in regard to institutional school characteristics, school composition (migrant population, ability levels), and industrial versus rural areas. In collaboration with teachers, students received informed consent forms addressed to their parents, indicating voluntary participation, assurance of anonymity, and confidentiality. Small incentives were given to participants during school break time and after the survey, because incentives were found to motivate respondents and thus increase the response rate (Singer \& Couper, 2008).

\subsection{Measures}

The new paper-and-pencil school alienation questionnaire was developed by applying a wellestablished systematic framework designed to produce reliable and valid scales (Hinkin, Tracey, \& Enz, 1997). The first crucial step in scale construction involved the creation of the initial pool of items meant to cover each content area relevant to the target construct and the sample. The items were developed by experienced theorists and researchers in the field based on the existing instruments (Hadjar \& Lupatsch 2010; Hascher \& Hagenauer 2010). The wording of each item was thoroughly discussed, to eliminate potential sources of constructirrelevant variance. A typical item represented a statement in regard to general positive or negative student feelings and thoughts toward classmates, teachers, and learning (e.g., "What we learn in school is boring"). 
Prior to application, a pilot study was conducted to test the developed instrument in Luxembourg and the Swiss canton of Bern. The pilot study examined how well the new measure reflected our expectation regarding its psychometric properties, and evaluated whether the construct of interest operated equivalently across two groups. After an initial assessment of the scale's reliability and validity, irrelevant, similar, or ambiguous items were eliminated from the study (e.g., "When I get bad grades, I do not feel good", "I wonder why working with a partner and group work are meaningful"). Accordingly, the final version of the SALS (consisting of 39 items, with 12-14 items per school alienation domain) was administered to assess school alienation among primary and secondary school students. A typical item represented a statement in regard to student feelings and thoughts toward classmates, teachers, and learning. An example of an item of alienation from the classmates scale is: "In my class I feel like someone who doesn't fit in"; alienation from the teachers scale: "I do not feel taken seriously by my teachers"; alienation from the learning scale: "I don't find pleasure in learning at school". For each item, students responded on a 4-point Likert scale with the endpoints $1=$ disagree to $4=$ agree. We chose this scale format to reach a specific respondent opinion; therefore, we eliminated the mid-point on the scale. In addition, shorter scales are relatively quick to use (Preston \& Colman, 2000). However, prior research has shown that there is often a give-and-take between scale reliability and ease of administration (as cited in Østerås et al., 2008). Several items in the survey were phrased in the reverse to force participants to carefully read the questions and to prevent the tendency to agree with a statement or respond in the same pattern throughout the questionnaire.

\section{Results}

\subsection{Descriptive statistics and reliability analysis}

Prior to conducting statistical analyses, we calculated the amount of missing data across the variables analyzed in this study to ensure robust data analysis. The largest amount of missing data was less than 3\%, which meant that accurate statistical estimates could be obtained (Acuña \& Rodriguez, 2004).

The reliability of the SALS was measured in terms of the internal consistency of the items and analyzed by calculating Cronbach's alpha (Hypothesis 1), using the Statistical Package for the Social Sciences (SPSS) Software Version 23. Using subsamples from primary and secondary school students in the Swiss canton of Bern, we conducted a reliability analysis by means of stepwise exclusion of the items with the lowest corrected item-total correlation. We then applied a series of factor analyses for all four subsamples to verify the factorial structure of the scale. Based on factor analysis and internal consistency of the items, 24 items, with 8 items per each school alienation domain, were selected for the final scale. The descriptive statistics for these 24 items and the school alienation scales are shown in Table 1. The Cronbach's alpha coefficients ranged from $\alpha=.74$ to $\alpha=.88$ for all study participants. The results of the reliability analyses confirmed Hypothesis 1 .

Table 1

Descriptive Statistics of School Alienation Scales

\begin{tabular}{|c|c|c|c|c|c|c|c|c|c|c|}
\hline \multirow{2}{*}{ Canton of Bern } & \multicolumn{5}{|c|}{ Primary school $(n=486)$} & \multicolumn{5}{|c|}{ Secondary school $(n=550)$} \\
\hline & $M$ & $S D$ & $\alpha$ & $S(S E)$ & $K(S E)$ & $M$ & $S D$ & $\alpha$ & $S(S E)$ & $K(S E)$ \\
\hline Classmates & 1.48 & .43 & .79 & $1.27(.11)$ & $1.45(.22)$ & 1.52 & .46 & .83 & $1.45(.11)$ & $2.50(.21)$ \\
\hline Teachers & 1.42 & .45 & .77 & $1.58(.11)$ & $3.29(.22)$ & 1.57 & .48 & .79 & $1.11(.11)$ & $1.39(.21)$ \\
\hline Learning & 1.54 & .52 & .87 & $1.34(.11)$ & $2.14(.22)$ & 1.83 & .56 & .88 & $1.13(.11)$ & $1.63(.21)$ \\
\hline \multirow{2}{*}{ Luxembourg } & \multicolumn{5}{|c|}{ Primary school $(n=503)$} & \multicolumn{5}{|c|}{ Secondary school $(n=534)$} \\
\hline & $M$ & $S D$ & $\alpha$ & $S(S E)$ & $K(S E)$ & $M$ & $S D$ & $\alpha$ & $S(S E)$ & $K(S E)$ \\
\hline Classmates & 1.56 & .50 & .74 & $1.29(.11)$ & $1.58(.22)$ & 1.60 & .52 & .84 & $1.25(.11)$ & $1.30(.21)$ \\
\hline Teachers & 1.61 & .59 & .79 & $1.10(.11)$ & $0.89(.22)$ & 1.77 & .59 & .83 & $0.90(.11)$ & $0.66(.21)$ \\
\hline Learning & 1.54 & .56 & .82 & $1.49(.11)$ & $2.23(.22)$ & 1.87 & .60 & .86 & $0.65(.11)$ & $0.17(.21)$ \\
\hline
\end{tabular}

Note. $M=$ mean; $S D=$ standard deviation; $\alpha=$ Cronbach's alpha; $S=$ skewness; $K=$ kurtosis; $S E=$ standard error. 
Intercorrelations of the school alienation factors for primary and secondary school students in both countries are reported in Table 2. Correlation coefficients displayed a positive association among the three domains of school alienation and represented small to high effects, indicating that the factors were conceptually and statistically distinguishable.

Table 2

Correlations among the Domains of School Alienation

\begin{tabular}{lcccccc}
\hline & \multicolumn{3}{c}{ Canton of Bern } & \multicolumn{3}{c}{ Luxembourg } \\
\cline { 2 - 6 } & 1 & 2 & 3 & 1 & 2 & 3 \\
\hline 1. Classmates & - & $.37^{* *}\left(.45^{* *}\right)$ & $.23^{* *}\left(.23^{* *}\right)$ & - & $.35^{* *}\left(.39^{* *}\right)$ & $.24^{* *}\left(.27^{* *}\right)$ \\
2. Teachers & $.44^{* *}\left(.55^{* *}\right)$ & - & $.50^{* *}\left(.56^{* *}\right)$ & $.38^{* *}\left(.48^{* *}\right)$ & - & $.49^{* *}\left(.56^{* *}\right)$ \\
3. Learning & $.25^{* *}\left(.29^{* *}\right)$ & $.40^{* *}\left(.44^{* *}\right)$ & - & $.27 * *\left(.33^{* *}\right)$ & $.51^{* *}\left(.57^{* *}\right)$ & -
\end{tabular}

Note. Values below the diagonal represent intercorrelations for primary school students ( $n=486$ students, canton of Bern; $n=503$ students, Luxembourg) and values above the diagonal represent intercorrelations for secondary school students ( $n=550$ students, canton of Bern; $n=534$ students, Luxembourg). Latent correlations revealed by CFAs are presented in parentheses. ${ }^{* *} p<.01$.

\subsection{Factorial structure of the SALS}

Prior to analyzing the factorial structure of the SALS, the data were screened to assure their appropriateness for confirmatory factor analysis (CFA) and the statistical estimator. The results from a Shapiro-Wilk test of normality, which considers the values of both Skewness and Kurtosis simultaneously, revealed that the data significantly deviate from a normal distribution $(p<.05)$. Some indicators demonstrated substantial non-normality, thereby weakening the assumption of multivariate normality. Having non-normal continuous indicators, we applied an estimator with robust standard errors and a chi-square test statistic, i.e., robust maximum likelihood estimation method (MLR), to achieve reliable statistical results (Brown, 2015). This allows evaluating models with missing data and provides parameter estimates, which are robust to nonnormality (Brown, 2015). All analyses were based on covariance structures and applied robust maximum likelihood estimation.

By applying CFA using software package Mplus Version 7.31, we assessed the internal validity of the SALS. In other words, we explored whether the SALS combined the variables that were collinear and belonged to the same underlying variable due to their mutual association. We estimated a range of the most significant fit indices as measures of model fit (Schermelleh-Engel, Moosbrugger, \& Müller, 2003), including the chisquare test statistic, the root mean square error of approximation (RMSEA), the comparative fit index (CFI), and the standardized root mean square residual (SRMR). The following typical criteria were applied to assess the adequacy of model fit: CFI of close to .95, RMSEA and SRMR of close to .05 (Hu \& Bentler, 1999; Schermelleh-Engel et al., 2003), and $\chi^{2} / d f<2$ (Hair, Anderson, Tatham, \& Black, 1995; Schermelleh-Engel et al., 2003). In addition, we performed the chi-square difference tests to compare several competing models against each other.

In the first confirmatory factor analysis, we assessed the hypothesized measurement model (see Figure 1, Model 3). It incorporated the three factors of school alienation, i.e., classmates, teachers, and learning, each consisting of 8 items. Within each domain, several items were used to indicate an emotional component and other items were used to indicate a cognitive component. The three factors were free to correlate. As can be seen in Table 3, the hypothesized model indicated a very good fit for primary as well as secondary school students in both Luxembourg and the Swiss canton of Bern. Completely standardized item loadings on the three factors of school alienation were all statistically significant and above .50 (primary school in both 
countries) and .57 (secondary school in both countries). Latent correlations among the three school alienation factors were moderate, reaching on average .50 for all subsamples.

Model 1

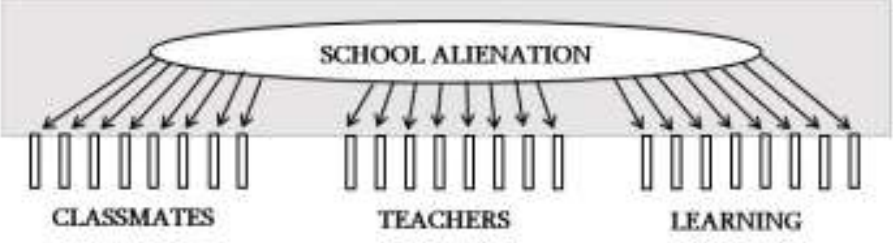

Model 2

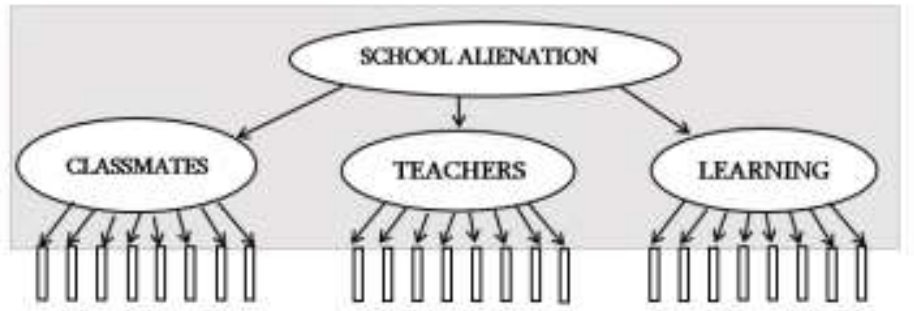

Model 4

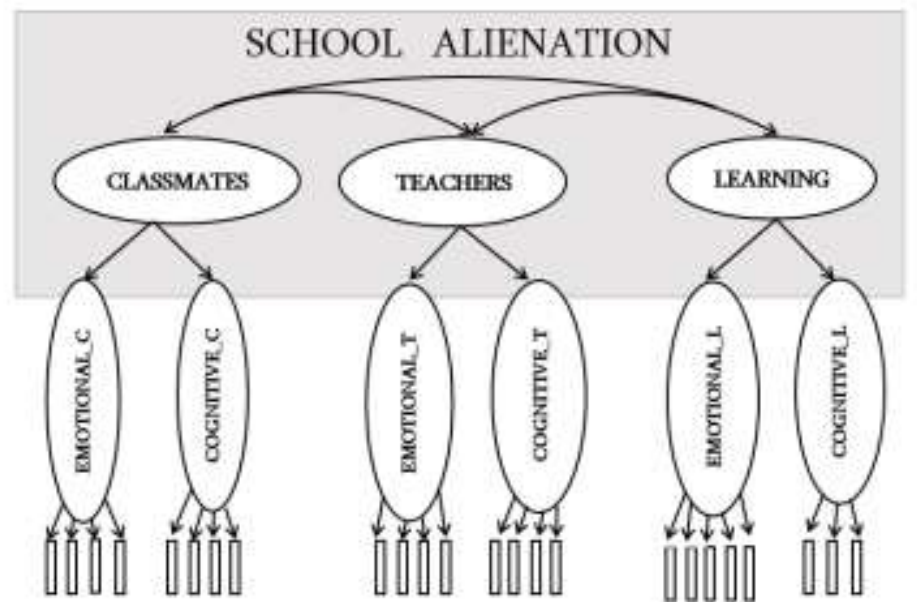

Model 3

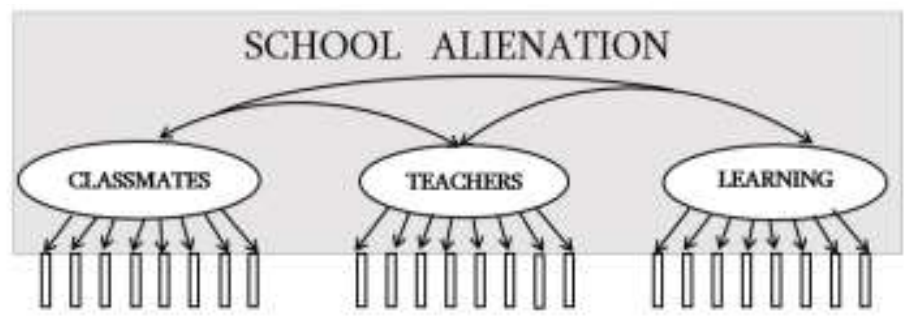

Figure 1. First-order one-factor (Model 1), second-order with three facets included (Model 2), hypothesized first-order three-factor (Model 3), and second-order with six facets included (Model 4) models potentially underlying the SALS.

\subsection{Competing models of school alienation}

Facilitating the assessment of the factorial validity of the SALS, we evaluated three alternative models against the hypothesized Model 3 (see Figure 1, Models 1, 2, 4). The models were subsequently compared in regard to their model fit by applying chi-square difference testing using the Satorra-Bentler scaled chi-square, in which the usual chi-square statistic is divided by a scaling correction to better approximate chi-square under non-normality (Brown, 2015). In Model 1, we assessed whether the data could be better described by an overall construct of school alienation in which no factors of school alienation were assumed. In Model 2, we specified that three school alienation domains load on one higher-order school alienation factor. Model 4 postulated that emotional and cognitive components comprised each of the three school alienation domains.

As can be seen in Table 3, none of the competing models provided a better fit to the data than the hypothesized first-order three-factor model for both primary and secondary school students in either Luxembourg or the Swiss canton of Bern. In both groups, chi-square difference tests revealed that the comparison between Model 1 and Model 3 was highly significant $(p<.01)$, indicating that Model 3 fits the data better than Model 1. Comparing Model 2 and Model 3, in all subgroups except for primary school in the canton of Bern, the chi-square difference test was statistically non-significant; this indicated that both models fit statistically equally well. The corrected difference test between Model 3 and Model 4 generated statistically 
insignificant values $(p>.01)$, indicating that the fit of the restricted model (Model 3) was not significantly worse than the fit of the unrestricted model (Model 4; see Table 3). In other words, both models function equally across the Swiss and the Luxembourgish primary and secondary school samples. Thus, the null hypothesis of equal fit for both models cannot be rejected. In addition, a confirmatory factor analysis of Model 4 revealed latent correlations between emotional and cognitive components in each of the three domains of school alienation. These correlations almost reached a perfect positive correlation (above .90), which indicates that both components undergo the same directional change. On the basis of these findings and theoretical considerations, we believe that emotional and cognitive components could be viewed as a single factor, as specified in Model 3. In keeping with Hypothesis 2, the hypothesized Model 3 is verified and fits the data better than alternative models.

Table 3

Goodness of Fit Indices for the Four Models of the SALS

\begin{tabular}{|c|c|c|c|c|c|c|c|c|c|c|}
\hline \multicolumn{11}{|c|}{ Canton of Bern } \\
\hline Model & $\chi^{2}$ & $d f$ & $\chi^{2} / d f$ & CFI & RMSEA & SRMR & $\begin{array}{c}\text { Model } \\
\text { Comparison } \\
\end{array}$ & $\Delta \chi^{2}$ & $\Delta d f$ & $p$ \\
\hline \multicolumn{11}{|c|}{ Primary School $(n=486)$} \\
\hline Model 1 & 996.28 & 246 & 4.05 & .70 & .08 & .10 & - & - & - & - \\
\hline Model 2 & 417.11 & 244 & 1.71 & .93 & .04 & .06 & 2 vs. 3 & 25.91 & 1 & $<.01$ \\
\hline Model 3 & 401.29 & 243 & 1.65 & .94 & .04 & .05 & 3 vs. 1 & 319.84 & 3 & $<.01$ \\
\hline Model 4 & 401.44 & 242 & 1.66 & .94 & .04 & .05 & 4 vs. 3 & 0.46 & 1 & NS \\
\hline \multicolumn{11}{|c|}{ Secondary School $(\mathrm{n}=550)$} \\
\hline Model 1 & 1377.88 & 246 & 5.60 & .69 & .09 & .11 & - & - & - & - \\
\hline Model 2 & 471.49 & 244 & 1.93 & .94 & .04 & .05 & 2 vs. 3 & 0.27 & 1 & NS \\
\hline Model 3 & 471.56 & 243 & 1.94 & .94 & .04 & .05 & 3 vs. 1 & 597.97 & 3 & $<.01$ \\
\hline Model 4 & 468.28 & 242 & 1.94 & .94 & .04 & .05 & 4 vs. 3 & 2.95 & 1 & NS \\
\hline \multicolumn{11}{|c|}{ Luxembourg } \\
\hline Model & $\chi^{2}$ & $d f$ & $\chi^{2} / d f$ & CFI & RMSEA & SRMR & $\begin{array}{c}\text { Model } \\
\text { Comparison }\end{array}$ & $\Delta \chi^{2}$ & $\Delta d f$ & $p$ \\
\hline \multicolumn{11}{|c|}{ Primary School $(\mathrm{n}=503)$} \\
\hline Model 1 & 825.85 & 246 & 3.36 & .73 & .07 & .08 & - & - & - & - \\
\hline Model 2 & 360.34 & 244 & 1.48 & .95 & .03 & .05 & 2 vs. 3 & 0.30 & 1 & NS \\
\hline Model 3 & 360.56 & 243 & 1.48 & .95 & .03 & .05 & 3 vs. 1 & 197.72 & 3 & $<.01$ \\
\hline Model 4 & 356.80 & 242 & 1.47 & .95 & .03 & .05 & 4 vs. 3 & 2.92 & 1 & NS \\
\hline \multicolumn{11}{|c|}{ Secondary School $(\mathrm{n}=534)$} \\
\hline Model 1 & 1465.46 & 246 & 5.96 & .65 & .10 & .11 & - & - & - & - \\
\hline Model 2 & 451.97 & 244 & 1.85 & .94 & .04 & .05 & 2 vs. 3 & 0.14 & 1 & NS \\
\hline Model 3 & 452.10 & 243 & 1.86 & .94 & .04 & .05 & 3 vs. 1 & 789.81 & 3 & $<.01$ \\
\hline Model 4 & 447.44 & 242 & 1.85 & .94 & .04 & .05 & 4 vs. 3 & 4.05 & 1 & NS \\
\hline
\end{tabular}




\subsection{Measurement invariance}

Pursuing the goals of evaluating the recently constructed research instrument and facilitating crosscultural research, we tested measurement invariance across primary and secondary school students in Luxembourg and the Swiss canton of Bern (Hypotheses 3 and 4) using multigroup confirmatory factor analyses. It is broadly recognized as one of the most successful and multilateral approaches to testing measurement invariance across specific groups of interest (Steenkamp \& Baumgartner, 1998). Examining measurement invariance through a series of models, we investigated whether the instrument possesses the same psychometric characteristics across various groups (Milfont \& Fischer, 2010; Schmitt \& Kuljanin, 2008).

This procedure included testing hierarchically arranged models: (a) a configural invariance model, (b) a metric invariance model, (c) a scalar invariance model, and (d) a residual invariance model. First, configural invariance indicated whether respondents from Luxembourg and the Swiss canton of Bern considered the construct of interest in a similar fashion, assuming the same item to be associated with the same latent factor in each group (Milfont \& Fischer, 2010). In this model, none of the parameters were constrained to be equal across the groups. All subsequent models in testing for invariance were compared against the fit of the configural model, serving as a baseline value (Byrne, 2012). At each step of the measurement invariance test procedure, earlier specified constraints remained in force. In the next step, metric invariance was required to test the equivalence of item factor loadings across the two groups, namely, whether participants in different groups assigned the same meaning to the items of a latent construct. Previous research has shown that at least partial metric invariance must be confirmed prior to conducting the subsequent tests (Vandenberg \& Lance, 2000). Furthermore, scalar invariance, constraining item intercepts to be the same across groups, was a prerequisite for the comparison of latent means between groups. Finally, having all previous constraints in place, we applied residual invariance to test the equivalence of measurement error for each item between groups (Byrne, 2012; Chen, Sousa, \& West, 2005; Milfont \& Fischer, 2010).

Following the recommendations for testing measurement invariance with an adequate sample size that is equal between the groups ( $\mathrm{N}>300$; Chen, 2007), we compared the three fit indices (i.e., CFI, RMSEA, and SRMR) across all invariance models. In compliance with the suggested guidelines, for testing metric invariance, a change of $\geq-.010$ in CFI, complemented by a change of $\geq .015$ in RMSEA, or a change of $\geq .030$ in SRMR indicates noninvariance; for testing scalar or residual invariance, a change of $\geq-.010$ in CFI, in addition to a change of $\geq .015$ in RMSEA, or a change of $\geq .010$ in SRMR indicates noninvariance. In both primary and secondary school samples, $\triangle \mathrm{CFI}, \triangle \mathrm{RMSEA}$, and $\triangle$ SRMR were evidently below the recommended cutoff values, and each of the four invariance models produced an acceptable fit (see Table 4). The chi-square difference test between Model 3 and Model 2 in both samples was significant $\left(\Delta \chi^{2}=130.43\right.$, $\Delta d f=24, p<.001 ; \Delta \chi^{2}=170.53, \Delta d f=24, p<.001$, respectively). Given that the test was based on large samples $\left(n_{\text {prim }}=989 ; n_{\mathrm{sec}}=1,084\right)$ and the decrease in CFI was below .01 , we concluded that there was no substantial difference between Luxembourgish and Swiss students on the intercepts of the measured variables (see Ong \& van Dulmen, 2006). Based on the three indicators, metric, scalar, and residual invariance between the Luxembourgish and Swiss primary and secondary school students was confirmed, revealing the equivalence of loadings, intercepts, and residuals across the two countries. Consistent with Hypotheses 3 and 4 , results suggest that the questionnaire works equally well for primary and secondary school students in both Luxembourg and Switzerland.

Finally, after confirming that the instrument possesses the same psychometric characteristics across two countries, we tested measurement invariance across male and female students in primary and secondary schools (Hypotheses 5). Based on the goodness-of-fit statistics, all four models provided an acceptable fit (all RMSEAs were below .05 and all CFIs were above .90; Schermelleh-Engel et al., 2003). Thus, the assumption of measurement invariance cannot be rejected, indicating that the SALS is measurement invariant for gender across primary and secondary schools. 
Table 4

Measurement Invariance Tests for the Three-Factor Model of School Alienation across Swiss and Luxembourgish Primary and Secondary School Students

\begin{tabular}{|c|c|c|c|c|c|c|c|c|c|c|}
\hline \multirow{2}{*}{\multicolumn{2}{|c|}{ Model }} & \multicolumn{5}{|c|}{ Overall Fit Indices } & \multirow{2}{*}{$\begin{array}{c}\text { Model } \\
\text { Comparison }\end{array}$} & \multicolumn{3}{|c|}{ Comparative Fit Indices } \\
\hline & & $\chi^{2}$ & $d f$ & CFI & RMSEA & SRMR & & $\Delta \chi^{2}$ & $\Delta d f$ & $\triangle \mathrm{CFI}$ \\
\hline \multicolumn{11}{|c|}{ Swiss $(n=486)$ and Luxembourgish $(n=503)$ primary school sample } \\
\hline 1. & Configural invariance & 761.35 & 486 & .94 & .04 & .05 & - & - & - & - \\
\hline 2. & Metric invariance & 803.92 & 507 & .94 & .04 & .05 & 2 vs. 1 & 40.66 & 21 & .00 \\
\hline 3. & Scalar invariance & 915.07 & 531 & .93 & .04 & .06 & 3 vs. 2 & $130.43 *$ & 24 & .01 \\
\hline 4. & Residual invariance & 929.35 & 537 & .93 & .04 & .06 & 4 vs. 3 & 13.31 & 6 & .00 \\
\hline \multicolumn{11}{|c|}{ Swiss $(n=550)$ and Luxembourgish $(n=534)$ secondary school sample } \\
\hline 1. & Configural invariance & 923.31 & 486 & .94 & .04 & .05 & - & - & - & - \\
\hline 2. & Metric invariance & 949.64 & 507 & .94 & .04 & .05 & 2 vs. 1 & 28.31 & 21 & .00 \\
\hline 3. & Scalar invariance & 1099.31 & 531 & .93 & .05 & .06 & 3 vs. 2 & $170.53 *$ & 24 & .01 \\
\hline 4. & Residual invariance & 1103.59 & 537 & .93 & .04 & .06 & 4 vs. 3 & 5.79 & 6 & .00 \\
\hline
\end{tabular}

Note. CFI = Comparative fit index; RMSEA = root mean squared error of approximation; SRMR = standardized root mean square residual; $\Delta=$ difference between the comparison and nested model. $\Delta$ RMSEA and $\Delta$ SRMR were explicitly below the recommended cutoff values. $* p<.001$.

\subsection{External validity of the SALS}

To provide additional evidence of construct validity, we estimated the relationship between the SALS and external criteria by means of correlational evidence. Criterion-related evidence is viewed as a gold standard in validation research (Chan, 2014; Kane, 2001; Sireci, 2009). Well-being dimensions were chosen as criterion variables from Hascher's (2004) questionnaire on subjective well-being in school (Donat, Peter, Dalbert, \& Kamble, 2016; Hascher, 2007, 2008, 2010; Hascher \& Hagenauer, 2011). The scale was validated in four countries, namely, Germany, Switzerland, the Czech Republic, and the Netherlands (Hascher, 2007). Specifically, we examined the relationship between the school alienation domains and (a) enjoyment and positive attitudes to school (Hypothesis 6) and (b) social problems in school (Hypothesis 7). These welldefined measures demonstrated high quality and reliability in prior research (Hascher, 2008; Hascher \& Hagenauer, 2011). The strength of the relationships between the SALS and the external criteria based on a Spearman's test is presented in Table 5. Strength of association indices was interpreted according to Cohen (1992). The pattern of correlations between the school alienation domains and well-being dimensions was highly alike between the Luxembourgish and Swiss samples. In keeping with our expectations, there were weak to strong significant negative associations between the domains of school alienation and the three positive well-being dimensions (positive attitudes toward school, enjoyment in school, and academic selfconcept). Specifically, correlation coefficients between each of the domains of school alienation and positive attitudes toward school ranged from $r=-.24(p<.01)$ to $r=-.59(p<.01)$ in the Swiss canton of Bern and from $r=-.26(p<.01)$ to $r=-.55(p<.01)$ in Luxembourg. Furthermore, there were weak to medium positive associations between alienation from classmates/teachers and social problems in school in both countries $(r=$ $.17-.45, p<.01)$. In addition, a small positive correlation was discovered between alienation from classmates/teachers and worries in school, whereas physical complaints had a weak positive association with all three domains of school alienation. 
Table 5

Correlations between the Factors of School Alienation and Dimensions of School-Specific Well-Being

\begin{tabular}{|c|c|c|c|c|c|c|}
\hline & \multicolumn{3}{|c|}{ Canton of Bern } & \multicolumn{3}{|c|}{ Luxembourg } \\
\hline & Classmates & Teachers & Learning & Classmates & Teachers & Learning \\
\hline Positive Attitudes & $-.24 * *(-.28 * *)$ & $-.30^{* *}\left(-.33^{* *}\right)$ & $-.59 * *(-.54 * *)$ & $-.26 * *(-.29 * *)$ & $-.32 * *(-.41 * *)$ & $-.51 * *(-.55 * *)$ \\
\hline Enjoyment & $-.23 * *(-.17 * *)$ & $-.34 * *(-.30 * *)$ & $-.43 * *(-.42 * *)$ & $-23 * *(-.28 * *)$ & $-.30 * *(-.44 * *)$ & $-.37 * *(-.48 * *)$ \\
\hline Self-Concept & $-.19 * *(-.23 * *)$ & $-.22 * *(-.25 * *)$ & $-.26 * *(-.28 * *)$ & $-.11 *(-.18 * *)$ & $-.27 * *(-.30 * *)$ & $-.24 * *(-.28 * *)$ \\
\hline Worries & $.09 *(.19 * *)$ & $.14 * *(.16 * *)$ & $-.02(.03)$ & $.05(.13 * *)$ & $.16^{* *}(.14 * *)$ & $.05(.02)$ \\
\hline Physical Complaints & $.11 *(.17 * *)$ & $.16 * *(.21 * *)$ & $.05(.11 * *)$ & $.08(.24 * *)$ & $.21 * *(.34 * *)$ & $.18 * *(.13 * *)$ \\
\hline Social Problems & $.35 * *(.39 * *)$ & $.22 * *(.17 * *)$ & $.10 *(.08)$ & $.36 * *\left(.45^{* *}\right)$ & $.30 * *(.26 * *)$ & $.20 * *(.09 *)$ \\
\hline
\end{tabular}

Note. Values without brackets represent correlations for primary school students ( $n=486$ students, canton of Bern; $n=$ 503 students, Luxembourg) and values within brackets represent correlations for secondary school students $(n=550$ students, canton of Bern; $n=534$ students, Luxembourg). ${ }^{*} p<.05 .{ }^{*} p<<.01$.

\section{Discussion and conclusion}

This study investigated the reliability and validity of a newly developed scale intended to measure school alienation (School Alienation Scale, SALS). School alienation was operationalized as student alienation from the most relevant domains in the context of schooling, namely, classmates, teachers, and learning. To our knowledge, to date there has been a dearth of well-crafted evaluations of student alienation from school (Brown et al., 2003b). Thus, this research enriches previous studies on school alienation and presents a comprehensive and psychometrically sound standardized measurement instrument to assess school alienation. The instrument consistently demonstrated strong psychometric properties, external validity, and measurement invariance across two countries - Luxembourg and Switzerland. We applied a binational approach to validate the construct of school alienation in two countries with different educational systems, thus contributing to comparative research and the generalizability of the study results. Our study furthermore considers both social actors and academic aspects of schooling as well as the state-of-the-art research on the interplay between emotional and cognitive processes (Dai \& Sternberg, 2004; Linnenbrink \& Pintrich, 2004; Pessoa, 2008).

School alienation emerged in three distinct but closely related domains. In accordance with the theory, the results of this study supported prior research that school alienation stems from three experiences. First, alienation from teachers reflects the idea that poor interactions between students and teachers, whom students may perceive as being unmotivated, nonsupportive, and disrespectful, facilitate development of alienation (Hascher, 2010; Kagan, 1990; Legault et al., 2006). Second, students alienated from classmates are exposed more than most adolescents to social isolation and have fewer important relationships with other people; they experience academic misfortune and a lack of identification with a school environment (Buhs \& Ladd, 2001; Ladd, Birch, \& Buhs, 1999). Third, students alienated from learning are less likely to participate in school lessons and learning activities; they experience a negative association with the educational environment and perceive school life as worthless (Çağlar, 2013; Carlson, 1995). However, social relations might mediate the relationship between negative school experience and alienation (Hascher, 2010). In each of the three school alienation domains, we have found an almost perfect positive correlation between emotional and cognitive components, indicating that cognition and emotion are interwoven psychological processes and undergo the same directional change.

The results of the reliability analysis supported Hypothesis 1, indicating the SALS to be a reliable measure of school alienation. The three subscales of the SALS, namely, alienation from classmates, teachers, and learning, displayed acceptable to very good reliability for both primary and secondary school students in both countries. Furthermore, a series of confirmatory factor analyses supported the postulated structure of the SALS, affirming its theoretical and scale validity. The hypothesized first-order three-factor model was 
particularly superior to three alternative models (Hypothesis 2 confirmed). This finding contributes to alienation research, indicating that students can be alienated from classmates, teachers, and/or learning at school. Although the three domains of school alienation were found to be correlated, there is no solid ground for a one-factor solution, implying that the factors of school alienation are conceptually and statistically distinguishable. This argues that no strong hierarchical structure underlies the SALS factors. We, therefore, provided additional evidence that school alienation can be addressed as a multidimensional domain-specific construct. Furthermore, even though the proposed competing model (in which emotional and cognitive components were considered as separate facets of school alienation domains; Model 4) fitted the data reasonably well, this study revealed that emotion and cognition are interwoven psychological processes. Nearly perfect positive correlations between emotional and cognitive components provided evidence that emotional and cognitive processes are closely related and cannot work independently of each other (Dai \& Sternberg, 2004; Eisenberg, 2014; Kreitler, 2013). Integrated understanding of intellectual functioning might be achieved through applying neurobiological approaches, which are generally disregarded in psychological research (Dai \& Sternberg, 2004). Applying the longitudinal cohort-sequential design, we will significantly improve the validity of conclusions suggested in this study.

With regard to Hypotheses 3, 4, and 5, this study revealed the measurement invariance of the threefactor model across Luxembourgish and Swiss primary and secondary school students and across gender (Hypotheses 3, 4, and 5 confirmed). These findings suggested that respondents from Luxembourg and the Swiss canton of Bern considered the construct of school alienation similarly and assigned the same meaning to the items. Support for scalar invariance indicated that the latent means can be significantly compared across groups (Milfont \& Fischer, 2010). Finally, the same level of measurement error was found for each item between groups, confirming residual invariance. Thus, the hypothesized three-factor model was found to be appropriate for both primary and secondary school students and may be used with both populations, regardless of student's gender.

In keeping with the idea that alienated youth are exposed to both physical and emotional disease (Farrow, 1991), the domains of school alienation could be associated with the dimensions of well-being. Consistent with Hypotheses 5 and 6, the SALS had a significant negative correlation to enjoyment and positive attitudes to school and a positive correlation with social problems in school. These significant moderate correlations were similar across the Swiss and Luxembourgish samples, providing additional evidence of the new instrument's validity. Thus, these findings indicated that the SALS had robust criterion-related validity; that is, the more individuals feel good and evaluate their current situation positively, the lower the level of their alienation (Vahedi \& Nazari, 2011). For example, when students appreciate activities and settings as well as value people in these settings, their alienation decreases and their psychological well-being increases (Ifeagwazi et al., 2015). In contrast, social discrimination in the classroom was found to lessen student wellbeing and intensify social problems in school (Hascher, 2010), because it is especially in adolescence that students experience a keen desire for peer interactions and want to be accepted by peers (Rubin, Bukowski, \& Parker, 1998; Safipour et al., 2011). Social alienation, in turn, was found to be one of the possible risk factors for health (Safipour et al., 2011). Research on well-being suggested that social support, positive interactions, and integration into the classroom maintained by teachers and classmates might stimulate student well-being (Hascher, 2010), thus diminishing their alienation from school and increasing their probability of becoming productive citizens. Applying a longitudinal design, further research could explore the transition from childhood to adulthood, when young people replace childish behavior with more mature behavior and which in turn may affect adolescent's psychological well-being (as cited in Safipour et al., 2011).

Although the hypothesized model and research hypotheses were supported, we identified several limitations of the present study. First, participation in this study was voluntary, assuming that the study sample might be biased. Given that prior to filling out a questionnaire we obtained written parent permission, it is possible that alienated students were underrepresented in the current study sample. We also recognize that there are limitations in regard to the instrument development process. Some items in the initial scale administered to students during the pilot study behaved differently for the Swiss and Luxembourgish samples, which resulted in substantial scale reduction. Although each item represented a particular situation, participants 
in Luxembourg and the Swiss canton of Bern might interpret items differently according to their feelings and thoughts toward classmates, teachers, and learning.

Since we were able to show that the final SALS operated in the same way across primary and secondary school students in Luxembourg and the Swiss canton of Bern, it is reasonable to expect cultural differences between the initial and new populations. We suggest that future studies include cognitive interviews with the participants during the pilot testing phase to obtain students' understanding of items and indicate problematic items for the new sample, or ascribe any difficulties with the test instructions to cultural differences. Further, cognitive interviews provide researchers with additional evidence regarding differences in item responses among participants from different samples. However, we assume that cognitive interviews could have influenced students' daily school life, because think-aloud conditions trigger participants to reflect upon their relationships with classmates and teachers as well as their attitudes toward learning.

In addition to the questionnaire, it would be useful to include a student standardized diary, in which students could specify their feelings and perceptions regarding classmates, teachers, and learning. This research method, which is strongly recommended to be applied more frequently in educational settings (Schmitz \& Wiese, 2006), would allow us to observe students' attitudes over time between different measurement time-points. Asking students to report their experiences in diaries would enable us to gain insight into participants' stances and give the students an opportunity for self-reflection. We believe that after rigorous preparation, both a questionnaire and a student diary might be administered using a computer.

Moreover, despite the confirmation of the proposed model, further domains of alienation, such as parental alienation (Kelly \& Johnston, 2001; Kocayörük \& Şimşek, 2015), may be useful for the analysis of school alienation. Separation or divorce may lead to parental alienation syndrome expressed in children's estrangement from their parents. In this sense, alienated children experience unreasonable negative feelings and beliefs toward one of their parents as a reaction to parents' divorce (Kelly \& Johnston, 2001). This syndrome might undermine not only parent-child and other interpersonal relationships, but also students' school performance and engagement with the school environment (Kocayörük \& Şimşek, 2015). In addition, parental attitudes toward school may also affect students' feelings about school (Ames, de Stefano, Watkins, \& Sheldon, 1995). Children tend to imitate parents' behavior and later adopt it as their own (Parsons, Adler, \& Kaczala, 1982). For example, parents' active participation and interest in what their children are learning have been found to enhance students' value of education and their academic motivation (Gonzalez-DeHass, Willems, \& Holbein, 2005). Longitudinal studies can reveal the development of school alienation, its causes, and consequences for students and education in general.

To conclude, the present study indicates that the SALS can be used as a valid and reliable research instrument in a variety of educational settings. The main finding of this study is that the hypothesized firstorder three-factor model, incorporating three school-related domains, namely, alienation from classmates, from teachers, and from learning, was confirmed. This finding is especially noteworthy because the disclosure of the core elements of school alienation, conceptually and statistically distinguishable, may contribute to further research and praxis. We also found that emotional and cognitive components of school alienation domains cannot be considered separately. The results of this study further show a negative association between school alienation domains and positive attitudes toward school; and a positive association between school alienation and social problems in school. This is the first study to clarify the defining elements of school alienation supporting the theoretically derived assumptions about the phenomenon of school alienation (see Hascher \& Hadjar, 2017). The results demonstrate the importance of detecting alienation symptoms among students in each of the three school alienation domains, as well as their causes and consequences. Understanding the school alienation phenomenon at different stages of development represents an important step in designing school-based prevention strategies to increase student well-being and academic success. While we know that the construct of school alienation operates equivalently in different educational contexts, it is necessary to observe the development of school alienation across time. In subsequent research, we need to apply a longitudinal cohort-sequential design and broaden our understanding of the school alienation phenomenon. 


\section{Keypoints}

We developed and validated a new 24-item questionnaire, the School Alienation Scale (SALS), to measure school alienation among primary and secondary school students.

* We disclosed the core elements of the school alienation construct: alienation from classmates, teachers, and learning.

We contributed to comparative research by validating the construct of school alienation in different educational settings.

- Carefully constructed, psychometrically sound, and brief multidimensional assessment instrument is practical for use in future studies.

\section{Acknowledgments}

We would like to thank the students and teachers who participated in the SASAL project. We also express our deepest gratitude to the research assistants who supported us during data collection and data entry processes. Our sincere appreciation is extended to PD Dr. Gerda Hagenauer, for her invaluable advice and expertise in data analysis. This study is supported by the Swiss National Science Foundation under Grant 100019L_159979 in Switzerland and the Luxembourg National Research Fund under Grant INTER/SNF/14/9857103 in Luxembourg.

\section{References}

Acuña, E., \& Rodriguez, C. (2004). The treatment of missing values and its effect on classifier accuracy. In D. Banks, F. R. McMorris, P. Arabie, \& W. Gaul (Eds.), Classification, clustering, and data mining applications (pp. 639-647). Springer Berlin Heidelberg. doi:10.1007/978-3-642-17103-1_60

Aiken, M., \& Hage, J. (1966). Organizational alienation: A comparative analysis. American Sociological Review, 31(4), 497-507.

Altenbaugh, R. J., Engel, D. E., \& Martin, D. T. (1995). Caring for kids: A critical study of urban school leavers. London: The Falmer Press.

American Educational Research Association, American Psychological Association, and National Council on Measurement in Education. (2014). Standards for Educational and Psychological Testing. Washington, DC: American Psychological Association.

Ames, C., de Stefano, L., Watkins, T., and Sheldon, S. (1995). Teachers' School-to-Home Communications and Parent Involvement: The Role of Parent Perceptions and Beliefs. Retrieved from: http://eric.ed.gov/?id=ED383451

Archambault, I., Janosz, M., Fallu, J. S., \& Pagani, L. S. (2009a). Student engagement and its relationship with early high school dropout. Journal of adolescence, 32(3), 651-670. doi:10.1016/j.adolescence.2008.06.007

Archambault, I., Janosz, M., Morizot, J., \& Pagani, L. (2009b). Adolescent behavioral, affective, and cognitive engagement in school: Relationship to dropout. Journal of school Health, 79(9), 408-415. doi:10.1111/j.1746-1561.2009.00428.x

Ariño, A. (2003). Measures of strategic alliance performance: An analysis of construct validity. Journal of international Business studies, 34(1), 66-79. doi:10.1057/palgrave.jibs.8400005

Aritzeta, A., Balluerka, N., Gorostiaga, A., Alonso-Arbiol, I., Haranburu, M., \& Gartzia, L. (2016). Classroom emotional intelligence and its relationship with school performance. European Journal of Education and Psychology, 9(1), 1-8. doi:10.1016/j.ejeps.2015.11.001 
Arnold, J. A., Arad, S., Rhoades, J. A., \& Drasgow, F. (2000). The empowering leadership questionnaire: The construction and validation of a new scale for measuring leader behaviors. Journal of Organizational Behavior, 21(3), 249-269.

Babad, E. (1992). Teacher expectancies and nonverbal behavior. In R. S. Feldman (Ed.), Applications of nonverbal behavioral theories and research (pp. 167-190). Hillsdale, NJ: Erlbaum.

Baker, J. A. (1998). Are we missing the forest for the trees? Considering the social context of school violence. Journal of School psychology, 36(1), 29-44.

Barnhardt, B., \& Ginns, P. (2014). An alienation-based framework for student experience in higher education: new interpretations of past observations in student learning theory. Higher Education, 68(6), 789-805. doi: 10.1007/s10734-014-9744-y

Becker, G. S. (1994). Human Capital Revisited. In G. S. Becker (Ed.), Human Capital: A Theoretical and Empirical Analysis with Special Reference to Education (pp. 15-28). Chicago: The University of Chicago Press.

Blauner, R. (1964). Alienation and freedom: The factory worker and his industry. The Sociological Quarterly, 6(1), 83-85. doi:10.2307/2574777

Brown, T. A. (2015). Confirmatory factor analysis for applied research. New York: Guilford Publications.

Brown, M. R., Higgins, K., \& Paulsen, K. (2003a). Adolescent alienation what is it and what can educators do about it? Intervention in School and Clinic, 39(1), 3-9. doi:10.1177/10534512030390010101

Brown, M. R., Higgins, K., Pierce, T., Hong, E., \& Thoma, C. (2003b). Secondary students' perceptions of school life with regard to alienation: The effects of disability, gender and race. Learning Disability Quarterly, 26(4), 227-238.

Buhs, E. S., \& Ladd, G. W. (2001). Peer rejection as antecedent of young children's school adjustment: An examination of mediating processes. Developmental psychology, 37(4), 550-560. doi:10.2307/1593636

Byrne, B. M. (2012). Structural equation modeling with Mplus: Basics, concepts, applications, and programming. New York: Routledge.

Çağlar, Ç. (2012). Development of the student alienation scale (SAS). Education and science, 37(166), 195205.

Çağlar, Ç. (2013). The Relationship between the Perceptions of the Fairness of the Learning Environment and the Level of Alienation. Eurasian Journal of Educational Research, 50, 185-206.

Carlson, T. B. (1995). We hate gym: Student alienation from physical education. Journal of teaching in Physical Education, 14(4), 467-477. doi:10.1123/jtpe.14.4.467

Case, J. M. (2008). Alienation and engagement: Development of an alternative theoretical framework for understanding student learning. Higher Education, 55(3), 321-332. doi:10.1007/s10734-007-9057-5

Chan, E.K.H. (2014). Standards and guidelines for validation practices: development and evaluation of measurement instruments. In B. D. Zumbo \& E. K. H. Chan (Eds.), Validity and validation in social, behavioral, and health sciences (pp. 9-24). Switzerland: Springer International Publishing. doi:10.1007/978-3-319-07794-9_2

Chen, F. F. (2007). Sensitivity of goodness of fit indexes to lack of measurement invariance. Structural equation modeling, 14(3), 464-504. doi:10.1080/10705510701301834

Chen, F. F., Sousa, K. H., \& West, S. G. (2005). Teacher's corner: Testing measurement invariance of secondorder factor models. Structural equation modeling, 12(3), 471-492. doi:10.1207/s15328007sem1203_7

Clark, L. A., \& Watson, D. (1995). Constructing validity: Basic issues in objective scale development. Psychological assessment, 7(3), 309-319. doi:10.1037/1040-3590.7.3.309

Cohen, J. (1992). A power primer. Psychological Bulletin, 112(1), 155-159. doi:10.1037/00332909.112.1.155

Crinson, I., \& Yuill, C. (2008). What can alienation theory contribute to an understanding of social inequalities in health? International Journal of Health Services, 38(3), 455-469. doi:10.2190/HS.38.3.e

Dai, D. Y., \& Sternberg, R. J. (2004). Beyond cognitivism: Toward an integrated understanding of intellectual functioning and development. In D. Y. Dai \& R. J. Sternberg (Eds.), Motivation, emotion, and cognition: Integrative perspectives on intellectual functioning and development (pp. 3-38). Mahwah, NJ: Lawrence Erlbaum. 
Dean, D. G. (1961). Alienation: Its meaning and measurement. American sociological review, 5, 753-758. doi: $10.2307 / 2090204$

Dekel, R., \& Tuval-Mashiach, R. (2012). Multiple losses of social resources following collective trauma: The case of the forced relocation from Gush Katif. Psychological Trauma: Theory, Research, Practice and Policy, 4(1), 56-65. doi:10.1037/a0019912

Dickey, M. (2004). The impact of web-logs (blogs) on student perceptions of isolation and alienation in a webbased distance-learning environment. Open learning, 19(3), 279-291. doi:10.1080/0268051042000280138

Donat, M., Peter, F., Dalbert, C., \& Kamble, S. V. (2016). The meaning of students' personal belief in a just world for positive and negative aspects of school-specific well-being. Social Justice Research, 29(1), 73 102. doi:10.1007/s11211-015-0247-5

Dweck, C. S., Mangels, J. A., Good, C. (2004). Motivational effects on attention, cognition, and performance. In D. Y. Dai \& R. J. Sternberg (Eds.), Motivation, emotion, and cognition: Integrative perspectives on intellectual functioning and development (pp. 41-55). Mahwah, NJ: Lawrence Erlbaum.

Fredricks, J. A., Blumenfeld, P. C., \& Paris, A. H. (2004). School engagement: Potential of the concept, state of the evidence. Review of educational research, 74(1), 59-109. doi:10.3102/00346543074001059

Eccles, J. S., \& Alfeld, C. A. (2007). Not you! Not here! Not now. In R. K. Silbereisen \& R. M. Lerner (Eds.), Approaches to positive youth development (pp. 133-156). Thousand Oaks, CA: Sage

Eccles, J. S., Brown, B. V., \& Templeton, J. L. (2008). A developmental framework for selecting indicators of well-being during the adolescent and young adult years. In B. V. Brown (Ed.), Key indicators of child and youth well-being: Completing the picture (pp. 197-236). Mahwah, NJ: Erlbaum.

Eccles, J., \& Gootman, J. A. (2002). Community programs to promote youth development. Washington, DC: National Academy Press. doi:10.17226/10022

Eccles, J. S., \& Midgley, C. (1989). Stage-environment fit: Developmentally appropriate classrooms for young adolescents. In C. Ames \& R. Ames (Eds.), Research on motivation in education (pp. 139-186). San Diego: Academic Press.

Eccles, J. S., \& Midgley, C. (1990). Changes in academic motivation and self-perception during early adolescence. In R. Montemayor, G. Adams, \& T. P. Gullotta (Eds.). From childhood to adolescence: A transitional period? (pp. 134-155). Newbury Park: Sage Publications.

Eccles, J. S., \& Roeser, R. W. (2009). Schools, academic motivation, and stage-environment fit. In R.M. Lerner \& L. Steinber (Eds.), Handbook of Adolescent Psychology (pp. 404-434). Hoboken, NJ: John Wiley \& Sons. doi:10.1002/9780470479193.adlpsy001013

Eisenberg, N. (2014). Altruistic Emotion, Cognition, and Behavior. New York, NY: Psychology Press.

Exline, J. J., Yali, A. M., \& Sanderson, W. C. (2000). Guilt, discord, and alienation: The role of religious strain in depression and suicidality. Journal of clinical psychology, 56(12), 1481-1496. doi:10.1002/10974679(200012)56:12<1481::AID-1>3.0.CO;2-A

Farrow, J. A. (1991). Youth alienation as an emerging pediatric health care issue. American Journal of Diseases of Children, 145(5), 491-492. doi:10.1001/archpedi.1991.02160050015002

Finifter, A. W. (1970). Dimensions of political alienation. American Political Science Review, 64(02), 389410. doi:10.2307/1953840

Frey, A., Ruchkin, V., Martin, A., \& Schwab-Stone, M. (2009). Adolescents in transition: School and family characteristics in the development of violent behaviors entering high school. Child Psychiatry and Human Development, 40(1), 1-13. doi:10.1007/s10578-008-0105-x

Ghaith, G. M., Shaaban, K. A., \& Harkous, S. A. (2007). An investigation of the relationship between forms of positive interdependence, social support, and selected aspects of classroom climate. System, 35(2), 229240. doi:10.1016/j.system.2006.11.003

Goetz, T., Frenzel, A. C., Pekrun, R., \& Hall, N. C. (2006). The domain specificity of academic emotional experiences. The Journal of Experimental Education, 75(1), 5-29.

Gonzalez-DeHass, A. R., Willems, P. P., \& Holbein, M. F. D. (2005). Examining the relationship between parental involvement and student motivation. Educational psychology review, 17(2), 99-123. doi:10.1007/s10648-005-3949-7 
Gottfried, A. E., Fleming, J. S., \& Gottfried, A. W. (2001). Continuity of academic intrinsic motivation from childhood through late adolescence: A longitudinal study. Journal of Educational Psychology, 93(1), 313. doi:10.1037/0022-0663.93.1.3

Gutman, L. M., \& Eccles, J. S. (2007). Stage-environment fit during adolescence: trajectories of family relations and adolescent outcomes. Developmental Psychology, 43(2), 522-537. doi:10.1037/00121649.43.2.522

Hadjar, A., Backes S., \& Gysin., S. (2015). School Alienation, Patriarchal Gender-Role Orientations and the Lower Educational Success of Boys. A Mixed-method Study. Masculinities and Social Change, 4(1), 85116. doi: $10.17583 / \mathrm{msc} .2015 .1319$

Hadjar, A., \& Lupatsch, J. (2010). Der Schul(miss)erfolg der Jungen. Kölner Zeitschrift für Soziologie und Sozialpsychologie, 62(4), 599-622. doi:10.1007/s11577-010-0116-Z

Hair, J. F., Anderson, R. E., Tatham, R. L., \& Black, W. C. (1995). Multivariate data analysis. NJ: PrenticeHall.

Hall-Lande, J.A., Eisenberg, M.E., Christenson, S.L., \& Neumark-Sztainer, D. (2007). Social isolation, psychological health, and protective factors in adolescence. Adolescence, 42(166), 265-286.

Hascher, T. (2004). Wohlbefinden in der Schule. Münster: Waxmann.

Hascher, T. (2007). Exploring students' well-being by taking a variety of looks into the classroom. Hellenic Journal of Psychology, 4(3), 331-349.

Hascher, T. (2008). Quantitative and qualitative research approaches to assess student well-being. International Journal of Educational Research, 47(2), 84-96. doi:10.1016/j.ijer.2007.11.016

Hascher, T. (2010). Wellbeing. In P. Peterson, E. Baker \& B. McGaw (Eds.), International Encyclopedia of Education (pp. 732-738). Oxford: Elsevier. doi:10.1016/B978-0-08-044894-7.00633-3

Hascher, T. (2011). Wellbeing. In S. Järvelä (Ed.), Social and emotional aspects of learning (pp. 99-106). Oxford: Elsevier.

Hascher, T. (2012). Well-being and learning in school. In N. M. Seel (Ed.), Encyclopedia of the Sciences of Learning (pp. 3453-3456). Heidelberg: Springer.

Hascher, T., \& Hadjar, A. (2017). School Alienation - A review of theoretical approaches and educational research. SASAL-Manuscript, University of Bern/University of Luxembourg.

Hascher, T., \& Hagenauer, G. (2010). Alienation from school. International journal of educational research, 49(6), 220-232. doi:10.1016/j.ijer.2011.03.002

Hascher, T., \& Hagenauer, G. (2011). Schulisches Wohlbefinden im Jugendalter-Verläufe und Einflussfaktoren. In A. Ittel, H. Merkens, \& L. Stecher (Eds.), Jahrbuch Jugendforschung (pp. 15-45). Wiesbaden: VS. doi:10.1007/978-3-531-93116-6_1

Hilgard, E. R. (1980). The trilogy of mind: Cognition, affection, and conation. Journal of the History of the Behavioral Sciences, 16(2), 107-117. doi:10.1002/1520-6696(198004)16:2<107::AIDJHBS2300160202>3.0.CO;2-Y

Hinkin, T. R., Tracey, J. B., \& Enz, C. A. (1997). Scale construction: Developing reliable and valid measurement instruments. Journal of Hospitality \& Tourism Research, 21(1), 100-120. doi:10.1177/109634809702100108

Hirschfeld, R. R., \& Feild, H. S. (2000). Work centrality and work alienation: Distinct aspects of a general commitment to work. Journal of Organizational Behavior, 21, 789-800. doi: 10.1002/10991379(200011)21:7<789::AID-JOB59>3.0.CO;2-W

Honkanen, P., Verplanken, B., \& Olsen, S. O. (2006). Ethical values and motives driving organic food choice. Journal of Consumer Behaviour, 5(5), 420-430. doi: 10.1002/cb.190

Hu, L. T., \& Bentler, P. M. (1999). Cutoff criteria for fit indexes in covariance structure analysis: Conventional criteria versus new alternatives. Structural equation modeling: a multidisciplinary journal, 6(1), 1-55. doi:10.1080/10705519909540118

Hughes, J. N., Gleason, K. A., \& Zhang, D. (2005). Relationship influences on teachers' perceptions of academic competence in academically at-risk minority and majority first grade students. Journal of school psychology, 43(4), 303-320. doi:10.1016/j.jsp.2005.07.001 
Hyman, I., Cohen, I., \& Mahon, M. (2003). Student Alienation Syndrome: A paradigm for understanding the relation between school trauma and school violence. The California School Psychologist, 8(1), 73-86. doi:10.1007/BF03340897

Ifeagwazi, C. M., Chukwuorji, J. C., \& Zacchaeus, E. A. (2015). Alienation and psychological wellbeing: Moderation by resilience. Social Indicators Research, 120(2), 525-544. doi:10.1007/s11205-014-06021

Isen, A. M. (2004). Some perspectives on positive feelings and emotions: Positive affect facilitates thinking and problem solving. In A. S. R. Manstead, N. Frijda, \& A. Fischer (Eds.), Feelings and emotions: The Amsterdam symposium (pp. 263-281). Cambridge, NY: Cambridge University Press. doi.10.1017/CBO9780511806582.016

Jussim, L., \& Eccles, J. S. (1992). Teacher expectations II: Construction and reflection of student achievement. Journal of personality and social psychology,63(6), 947-961. doi:10.1037/00223514.63.6.947

Jussim, L., Eccles, J., \& Madon, S. (1996). Social perception, social stereotypes, and teacher expectations: Accuracy and the quest for the powerful self-fulfilling prophecy. In M. P. Zanna (Ed.). Advances in experimental social psychology (pp. 281-388). San Diego, CA: Academic Press. doi:10.1016/S00652601(08)60240-3

Kagan, D. M. (1990). How schools alienate students at risk: A model for examining proximal classroom variables. Educational Psychologist, 25, 105-125. doi:10.1207/s15326985ep2502_1

Kane, M. T. (2001). Current concerns in validity theory. Journal of educational Measurement, 38(4), 319-342.

Kelly, J. B., \& Johnston, J. R. (2001). The alienated child: A reformulation of parental alienation syndrome. Family Court Review, 39(3), 249-266. doi: 10.1111/j.1745-3984.2001.tb01130.x

Kocayörük, E., \& Şimşek, Ö. F. (2015). Parental Attachment and Adolescents' Perception of School Alienation: The Mediation Role of Self-Esteem and Adjustment. The Journal of psychology, 150(4), 405421. doi:10.1080/00223980.2015.1060185

Kreitler, S. (2013). Cognition and motivation: Forging an interdisciplinary perspective. Cambridge University Press.

Krumboltz, J. D. (2009). The happenstance learning theory. Journal of Career Assessment, 17(2), 135-154. doi:10.1177/1069072708328861

Ladd, G. W. (1999). Peer relationships and social competence during early and middle childhood. Annual Review of Psychology, 50(1), 333-359. doi:10.1146/annurev.psych.50.1.333

Ladd, G. W., Birch, S. H., \& Buhs, E. S. (1999). Children's social and scholastic lives in kindergarten: Related spheres of influence? Child Development, 70(6), 1373-1400. doi:10.1111/1467-8624.00101

Legault, L., Green-Demers, I., \& Pelletier, L. (2006). Why do high school students lack motivation in the classroom? Toward an understanding of academic amotivation and the role of social support. Journal of educational psychology, 98(3), 567. doi:10.1037/0022-0663.98.3.567

Linnenbrink, E. A., \& Pintrich, P. R. (2004). Role of affect in cognitive processing in academic contexts. In D. Y. Dai \& R. J. Sternberg (Eds.), Motivation, emotion, and cognition: Integrative perspectives on intellectual functioning and development (pp. 57-87). Mahwah, NJ: Lawrence Erlbaum. doi: $10.4324 / 9781410610515$

Liu, R. (2010). Alienation and First-Year Student Retention. Professional File, 116, 1-18.

Lumsden, L. S. (1994). Student motivation to learn. Research Roundup, 10(3),1-5.

Martin, J. (2008). Pedagogy of the alienated: Can Freirian teaching reach working-class students? Equity \& Excellence in Education, 41(1), 31-44. doi:10.1080/10665680701773776

Mau, R. Y. (1992). The validity and devolution of a concept: Student alienation. Adolescence, 27(107), 731741.

McKown, C., \& Weinstein, R. S. (2008). Teacher expectations, classroom context, and the achievement gap. Journal of school psychology, 46(3), 235-261. doi:10.1016/j.jsp.2007.05.001

MENJE \& University of Luxembourg (2015). Bildungsbericht Luxemburg 2015. Band 2: Analysen und Befunde. Luxembourg: MENJE. 
Messick, S. (1995). Validity of psychological assessment: Validation of inferences from persons' responses and performances as scientific inquiry into score meaning. American psychologist, 50(9), 741-749. doi:10.1037/0003-066X.50.9.741

Milfont, T. L., \& Fischer, R., (2010). Testing measurement invariance across groups: Applications in crosscultural research. International Journal of psychological research, 3(1), 111-121.

Moreno, E. S., \& de Roda, A. B. L. (2003). Social psychology of mental health: The social structure and personality perspective. The Spanish Journal of Psychology, 6(1), 3-11.

Murdock, T. B. (1999). The social context of risk: Status and motivational predictors of alienation in middle school. Journal of Educational Psychology, 91(1), 62-75. doi:10.1037//0022-0663.91.1.62

Newmann, F. M. (1992). Student engagement and achievement in American secondary schools. New York: Teachers College Press.

Ong, A. D., \& van Dulmen, M. H. (2006). Oxford handbook of methods in positive psychology. New York, NY: Oxford University Press.

Pantoja, A. D., \& Segura, G. M. (2003). Does ethnicity matter? Descriptive representation in legislatures and political alienation among Latinos. Social Science Quarterly, 84(2), 441-460. doi:10.1111/15406237.840201

Parsons, J. E., Adler, T. F., \& Kaczala, C. M. (1982). Socialization of achievement attitudes and beliefs: Parental influences. Child development, 53(2), 310-321. doi:10.2307/1128973

Pessoa, L. (2008). On the relationship between emotion and cognition. Nature reviews neuroscience, 9(2), 148-158. doi:10.1038/nrn2317

Preston, C. C., \& Colman, A. M. (2000). Optimal number of response categories in rating scales: reliability, validity, discriminating power, and respondent preferences. Acta psychologica, 104(1), 1-15. doi:10.1016/S0001-6918(99)00050-5

Railton, P. (2013). Alienation, Consequentialism, and the Demands of Morality. In R. Shafer-Landau (Ed.), Ethical Theory: An Anthology (pp. 441-457). John Wiley \& Sons, Inc.

Reinke, W. M., \& Herman, K. C. (2002). Creating school environments that deter antisocial behaviors in youth. Psychology in the Schools, 39(5), 549-559.

Rovai, A. P., \& Wighting, M. J. (2005). Feelings of alienation and community among higher education students in a virtual classroom. Internet and Higher Education, 8(2), 97-110. doi:10.1016/j.iheduc.2005.03.001

Rubin, K. H., Bukowski, W., \& Parker, J. G. (1998). Peer interactions, relationships, and groups. Handbook of child psychology, 3(5), 619-700.

Safipour, J., Schopflocher, D., Higginbottom, G., \& Emami, A. (2011). The mediating role of alienation in self-reported health among Swedish Adolescents. Retrieved from: http://www.tandfonline.com/doi/pdf/10.3402/vgi.v2i0.5805?needAccess=true

Schabracq, M., \& Cooper, C. (2003). To be me or not to be me: About alienation. Counselling Psychology Quarterly, 16(2), 53-79.

Schunk, D. H., \& Meece, J. (2005). Self-efficacy development in adolescence. In F. Pajares \& T. Urdan (Eds.), Self-efficacy beliefs during adolescence (pp. 71-96). Greenwich, CT: Information Age Publishing.

Schermelleh-Engel, K., Moosbrugger, H., \& Müller, H. (2003). Evaluating the fit of structural equation models: Tests of significance and descriptive goodness-of-fit measures. Methods of psychological research online, $8(2), 23-74$.

Schmitt, N., \& Kuljanin, G. (2008). Measurement invariance: Review of practice and implications. Human Resource Management Review, 18(4), 210-222. doi:10.1016/j.hrmr.2008.03.003

Schmitz, B., \& Wiese, B. S. (2006). New perspectives for the evaluation of training sessions in self-regulated learning: Time-series analyses of diary data. Contemporary educational psychology, 31(1), 64-96. doi:10.1016/j.cedpsych.2005.02.002

Seeman, M. (1959). On the meaning of alienation. American sociological review, 24, 783-791. doi: $10.2307 / 2088565$

Seeman, M. (1975). Alienation studies. Annual review of sociology, 1, 91-123. doi:10.1146/annurev.so.01.080175.000515 
Seetanah, B. (2009). The economic importance of education: evidence from Africa using dynamic panel data analysis. Journal of Applied Economics, 12(1), 137-157.

Shakespeare, W. (2000). Romeo and Juliet. Oxford, UK: Oxford University Press (Originally published in 1599).

Shantz, A., Alfes, K., \& Truss, C. (2014). Alienation from work: Marxist ideologies and twenty-first-century practice. The International Journal of Human Resource Management, 25(18), 2529-2550.doi: 10.1080/09585192.2012.667431

Sidorkin, A. M. (2004). In the event of learning: Alienation and participative thinking in education. Educational Theory, 54(3), 251-262.doi:10.1111/j.0013-2004.2004.00018.x

Singer, E., \& Couper, M. P. (2008). Do incentives exert undue influence on survey participation? Experimental evidence. Journal of Empirical Research on Human Research Ethics, 3(3), 49-56. doi:10.1525/jer.2008.3.3.49

Sireci, S. G. (2009). Packing and unpacking sources of validity evidence: History repeats itself again. In R. W. Lissitz (Ed.), The concept of validity: Revisions, new directions and applications (pp. 19-38). Charlotte, NC: Information Age Publishers.

Snow, R. E., Corno, L., \& Jackson D. (1996). Individual differences in affective and conative functions. In D. C. Berliner \& R. C. Calfee (Eds.), Handbook of educational psychology (pp. 243-310). New York: Macmillan.

Steenkamp, J. B. E., \& Baumgartner, H. (1998). Assessing measurement invariance in cross-national consumer research. Journal of consumer research, 25(1), 78-90. doi:10.1086/209528

Tarquin, K., \& Cook-Cottone, C. (2008). Relationships among aspects of student alienation and self concept. School Psychology Quarterly, 23(1), 16-25.

Tinto, V. (1975). Dropout from higher education: A theoretical synthesis of recent research. Review of Educational Research, 45(1), 89-125. doi:10.3102/00346543045001089

Tinto, V. (1993). Leaving college: Rethinking the causes of student attrition. Chicago: University of Chicago Press.

OECD. (2004). Learning for tomorrow's world: First results from PISA 2003. Paris: OECD Publishing. doi:10.1787/9789264006416-en

Osin, E. (2009). Subjective experience of alienation: Measurement and correlates. Gesellschaft fur Logotherapie und Existenzanalyse, 1(26), 16-23.

Østerås, N., Gulbrandsen, P., Garratt, A., Benth, J. Š., Dahl, F. A., Natvig, B., \& Brage, S. (2008). A randomised comparison of a four-and a five-point scale version of the Norwegian Function Assessment Scale. Health and quality of life outcomes, 6(14), 1-9. doi:10.1186/1477-7525-6-14

Stamm, M., Kost, J., Suter, P., Holzinger, M., \& Stroezel, H. (2011). Dropout CH: Schulabbruch und Absentismus in der Schweiz. Zeitschrift für Pädagogik, 57(2), 187-202.

Vahedi, S., \& Nazari, M. A. (2011). The relationship between self-alienation, spiritual well-being, economic situation and satisfaction of life: A structural equation modeling approach. Iranian Journal of Psychiatry and Behavioral Sciences, 5(1), 64-73.

Van de Schoot, R., Lugtig, P., \& Hox, J. (2012). A checklist for testing measurement invariance. European Journal of Developmental Psychology, 9(4), 486-492. doi:10.1080/17405629.2012.686740

Vandenberg, R. J., \& Lance, C. E. (2000). A review and synthesis of the measurement invariance literature: Suggestions, practices, and recommendations for organizational research. Organizational research methods, 3(1), 4-70. doi:10.1177/109442810031002

Vila, L. E. (2000). The non-monetary benefits of education. European journal of education, 35(1), 21-32. doi:10.1111/1467-3435.00003

Watt, I. (2000). Essays on Conrad. Cambridge University Press. doi:10.1017/CBO9780511485343

Wimmer, M. (2013). Motivation, Cognition, and Emotion: A Phylogenetic-Interdisciplinary Approach. In S. Kreitler (Ed.), Cognition and Motivation: Forging an Interdisciplinary Perspective (pp. 137-157). Cambridge University Press.

Young, I. M. (1984). Pregnant embodiment: Subjectivity and alienation. Journal of Medicine and Philosophy, 9(1), 45-62. doi:10.1093/jmp/9.1.45 
Zhang, C., \& Zhuang, L. (2011). The composition of human capital and economic growth: Evidence from China using dynamic panel data analysis. China Economic Review, 22(1), 165-171. doi:10.1016/j.chieco.2010.11.001

Zihl, I., Szesny, N., \& Nickel, T. (2013). Cognition in the Context of Psychopathology: A Selective Review. In S. Kreitler (Ed.), Cognition and Motivation: Forging an Interdisciplinary Perspective (pp. 76-95). Cambridge University Press. doi:10.1017/CBO9781139021463.007

Zumbo, B. D. (2009). Validity as contextualized and pragmatic explanation, and its implications for validation practice. In R. W. Lissitz (Ed.), The concept of validity: Revisions, new directions and applications (pp. 65-82). Charlotte, NC: Information Age Publishers. 